\title{
The Higher Education Functional Crisis: A Case of the University of Burundi
}

\author{
Ms. TUYISENGE Françoise ${ }^{1}$
}

\begin{abstract}
In this study, we develop factors influencing the functional crisis in the University of Burundi. Different actors of this institution contributed to the completion of this study through a questionnaire addressed via "Google Forms". Respondents were mainly students, teachers, and other personnel staff who responded to our questionnaire. Both qualitative and quantitative methods have been implemented. Interviews were conducted to gather the views of these stakeholders. In addition, the document review allowed the collection of additional information. The results of this study analysis show that University of Burundi crisis is pronounced and multifaceted. The characteristics of this University functional crisis that have just been raised are due to a number of factors determining them. These are basically economic, institutional and socio-political factors. Since 1980s, University of Burundi, like all other African universities, is facing the financial problems with the breakdown of major macroeconomic balances. We note that these institutions entered then a cycle of crises that recalls the dysfunction of all the device.
\end{abstract}

Keys words: Functional crisis, University of Burundi, Higher Education, University

\section{Résumé}

Dans cette étude, nous développons les facteurs influençant la crise fonctionnelle à l'Université du Burundi. Différents acteurs de cette institution ont contribué à la réalisation de cette étude à travers un questionnaire adressé via "Google Forms". Les répondants étaient principalement des étudiants, des enseignants et d'autres membres du personnel. Une méthode mixte c'est-à-dire qualitative et quantitative a été utilisée dans la collecte des données. Des entretiens ont été menés pour recueillir les points de vue de ces acteurs. En outre, la revue documentaire a permis la collecte des informations complémentaires. Les résultats de cette analyse montrent que la crise de l'Université du Burundi est une crise prononcée et multiforme. Les caractéristiques de cette crise fonctionnelle universitaire sont dues à un certain nombre de facteurs qui les déterminent. Il s'agit essentiellement des facteurs économiques, institutionnels et sociopolitiques. Depuis les années 1980, l'Université du Burundi, comme toutes les autres universités africaines, est confrontée au problème financier, dû̀ la rupture des grands équilibres macroéconomiques. Nous constatons que ces institutions sont alors entrées dans un cycle de crises qui rappelle le dysfonctionnement de tout le dispositif.

Mots clés : Crise de fonctionnement, Université du Burundi, Enseignement Supérieur, Université

\section{Introduction}

African higher education is experiencing a recurring crisis. The fact consists in a criticism without concession (Loiret, 2008).It is likely easy to notice that the crisis emerges as a complex phenomenon, as said clearly some authors (Diakité, 2000). African universities are labeled as if they "are not at the required level", they "are not up to the task", their curricula are "outdated", they have not been able to "adapt to the modern World". The fundamental problem of this system is its "inability to adapt" (World Bank, 1997).

This crisis is a reflection of both external and internal dynamics. The rapid increase in the number of students, the demographic explosion, the intellectual and cultural dependence on the West, the weakness of public funding, the brain drain, problems of institutional management and efficiency, the obstacles to women's access to university are all factors, obstacles or challenges that african higher education must face if it is to serve more than just a minority elite (Angula, 2003).

The crisis of higher education can be understood here in the sense of Hugon et al. (1994) describing the situation of academic institutions whose different functions are carried out in a confrontational manner, reflecting the dysfunctions/inefficiencies that characterize them. The theme of the crisis is not new in the literature on the education sector (Makosso, 2006).

\footnotetext{
${ }^{1}$ TUYISENGE Françoise is currently pursuing doctoral studies in joint supervision between Burundi University and Liege University in Political and Social Sciences doctorate. She already has her research in the framework of the universality of primary education during her end-of-studies work at the University of Liege. Currently, the field of concentration of her $\mathrm{PhD}$ thesis concerns educational issues, especially higher education in the World. Her research article is part of doctoral research studies which aim to develop constraints and opportunities of access in higher education to meet the current challenges.
} 
Despite the need to invest in higher education, UNESCO reports indicate that the sector is in crisis in almost all African countries. These difficulties worsened in the 1980s with the collapse of the major macroeconomic balances. Structural adjustment programs, which were very popular at the time, followed. These programs, whose fiscal austerity was the main maxim, led not only to the deterioration of study and supervision conditions, but also to an increased maladjustment of education to socio-economic realities. African universities have therefore entered a cycle of crises that calls into question all their functional devices (Nkouka, 2009, Chachage 2001, Abdelkader 2002).

The history of the University of Burundi (UB) goes back to the period that preceded the Independence. Indeed, the first in the country, this university was created in 1964 by the missionaries. In the 1980s, with the advent of structural and adjustment programs, the University of Burundi, like other African universities, began to face its first major crises (lack of resources, difficulties in redefining policy, etc.(Goudiaby,2009). We are thus witnessing a University that is left to its own devices and dependent, striving to meet the imperatives of development (Loiret, 2008).

The objective of this study is to determine factors influencing the functional crisis in University of Burundi. We sequentially present the results and interpret them, process by discussion and conclusion before addressing some recommendations.

\section{Methodology}

This study used mixed methods. We first consulted documents including reports on higher education in general and on university of Burundi in particular. Second, a questionnaire has been designated and addressed through Google Forms. Interviews have been additionally conducted.

Variety of actors constituting the population mostly teachers, personal staff at different levels, and students. Within this population, the questionnaire was addressed to 50 persons using their e-mails addresses. Unfortunately, and this is one of the main encountered problems, only 25 respondents regularly satisfied our requirements. Many of them responded partially to the questionnaire, choosing questions over others. We assumed that respondents should be as free as possible in their responses, instead of making questions required exposing to no response.

\section{Results Presentation}

The results of our investigation, based on the information gathered from some actors, reveal that the crisis of the UB is pronounced and multifaceted. It can be apprehended through elements that are either inputs for the system, either performance indicators of the system. Among the respondents, several actors stated that the functional crisis is characterized by weak qualification and unavailability of teachers, brain drain, no research structure performant, academic and social infrastructures not adapted to the moment conditions, limited funding capacity, dual operating regime since 2011 (problem adapting to the BMD regime), etc.

\section{Graph 1: Existence of functional crisis}

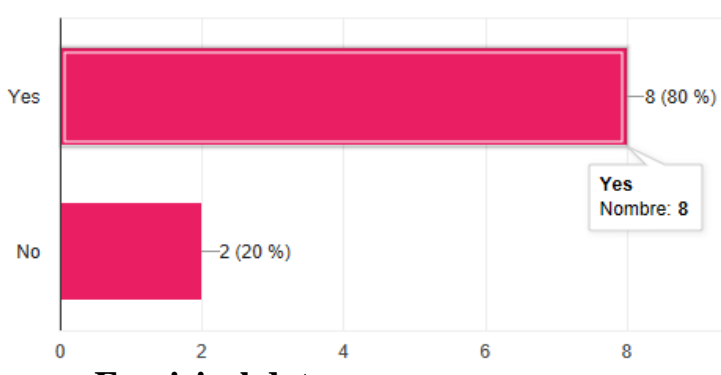

Graph 2: Appreciation degree of the crisis

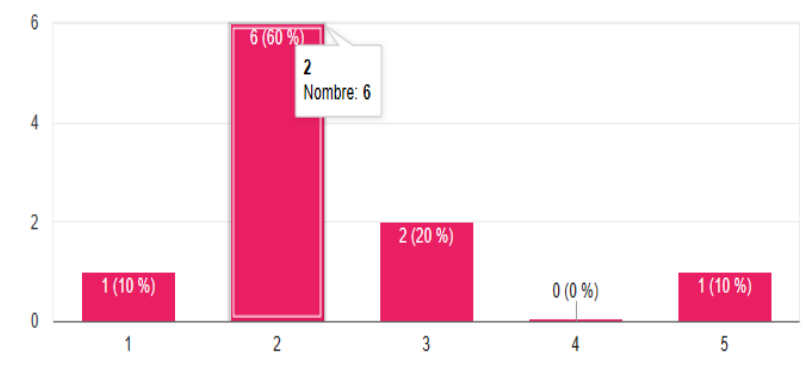

Source: Empirical data

The University of Burundi, as a public higher education institution has a large number of teachers and students. The statistical yearbook of teachers and students for the academic year 2017-18 shows that until February 2019, the number of full-time teachers at the University of Burundi (including seconded teachers) is 500 .

\section{Graph 3: Number of faculty members}

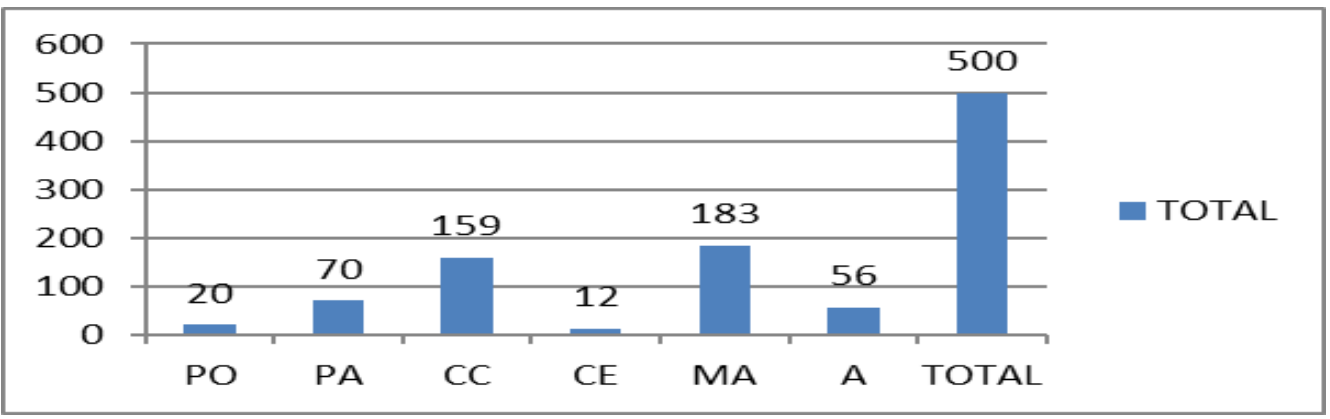


The below graph shows the state of these teachers considering age, and breakdown by faculty.

Graph 4: The university of Burundi teachers by faculty and age range

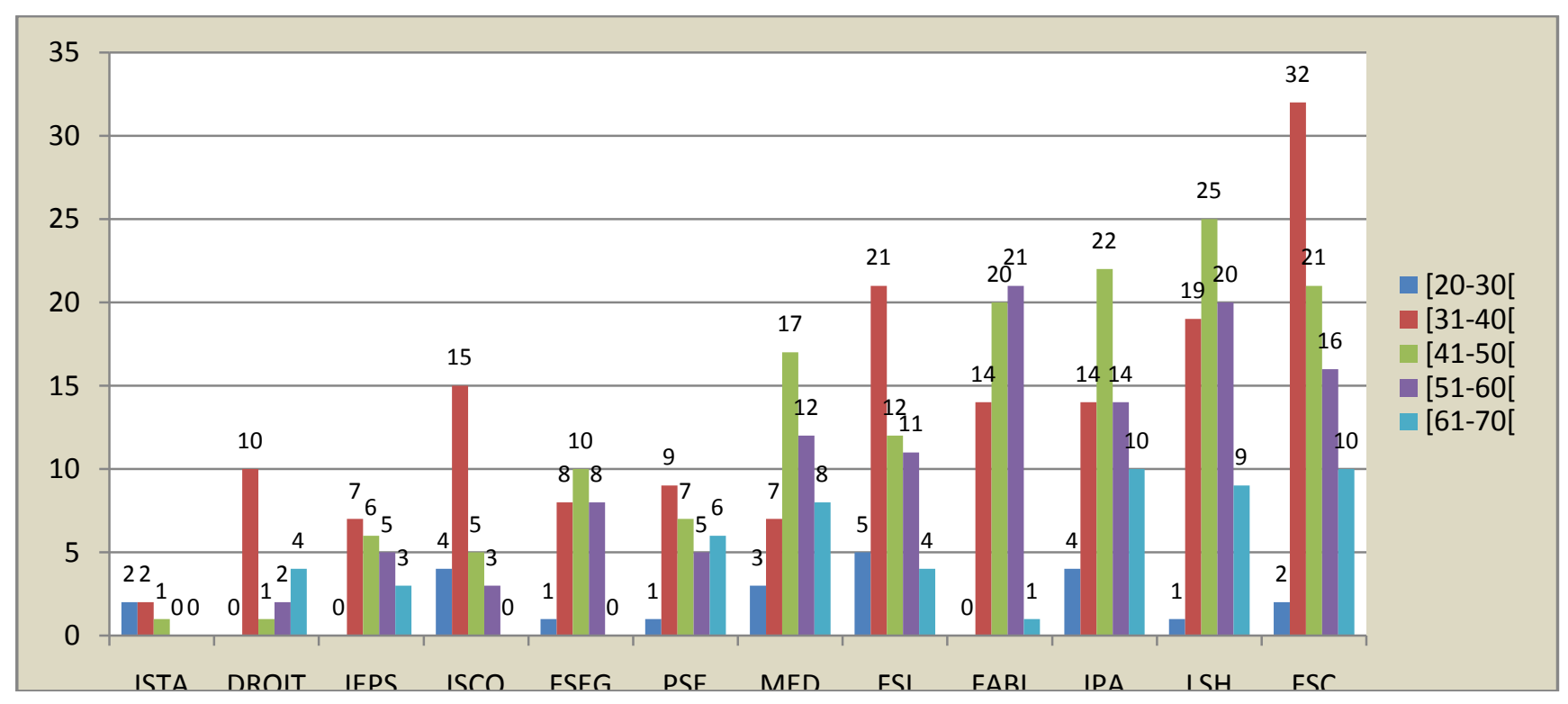

\section{Source: Statistical yearbook of teachers and students for the academic year 2017-18}

This figure generally shows that the majority of the teachers of the University of Burundi is between 31 to 60 years old $(422 / 500)$ is $84.4 \%$. The age group of 20 to 30 years is represented at $4.6 \%$ and that of 61 to 70 is represented at $11 \%$. Among these 500 teachers, only 69 are female.

This institution has experienced and continues to experience a brain drain. Some professors from the University of Burundi who go abroad for postgraduate studies do not return.

Research activities at this institution are nor systemically carried out nor published. University of Burundi is not well classified in the ranking process of world universities.

Existing academic and social infrastructure are not well equipped to support standard learning process. For example, libraries exist but their capacity reception is not enough and is no connected to internet, especially faculty and institute libraries. There is no electronic information policy for new documents. And if new books arrive, posters are made and they often include bachelor's degree papers and internship reports.

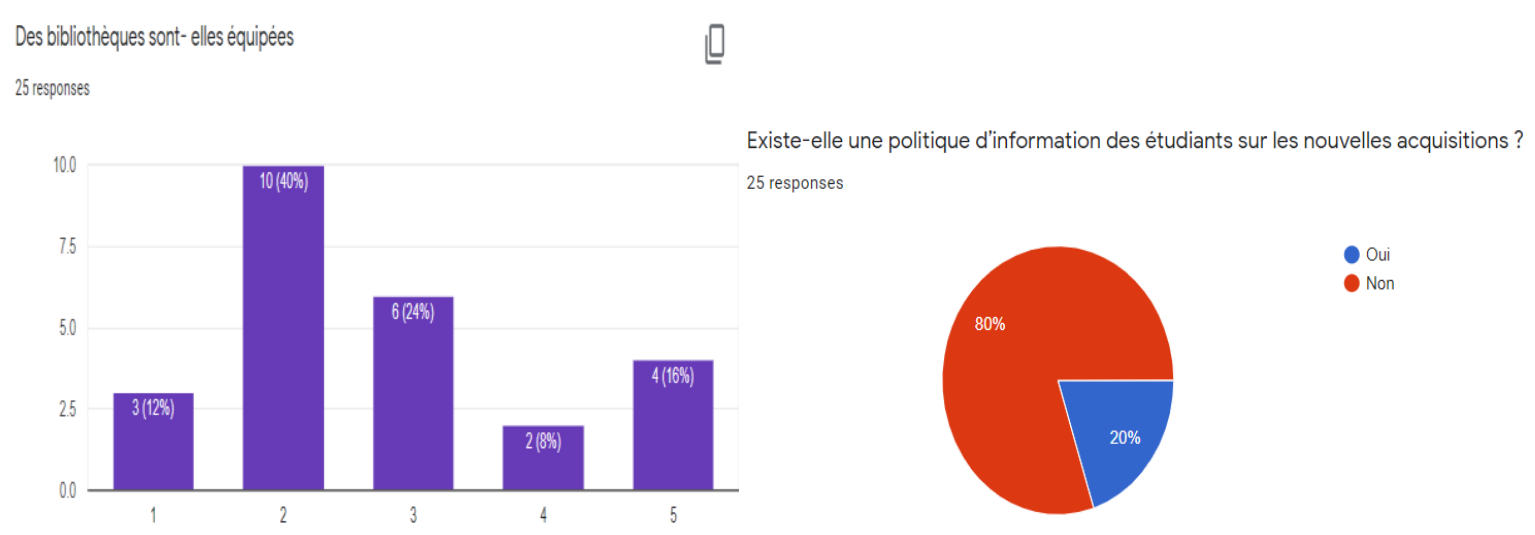

Source: Empirical data 
We observe a cohabitation of the two educational systems at the University of Burundi: the old system and the LMD introduced since the 2011-12 academic year. The UB funding freezes since 1980s and the institution receive mainly state subsidies for functioning and investment. But this fund is not well shared to all categories as shown below.

\section{Graph 5: Trend of expenses of UB in $2006-2010$}

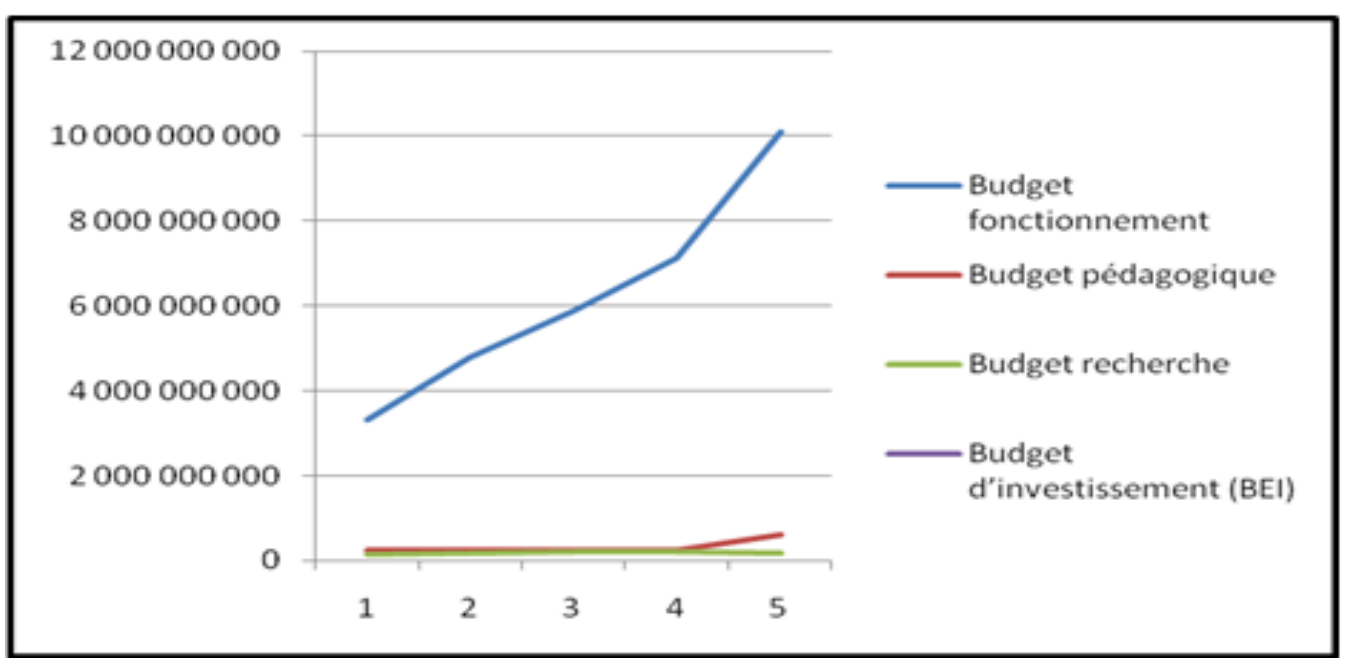

\section{Source: Analysis of public higher education financing and functioning in Burundi}

Compared to other levels of education, higher education in French-speaking countries is poorly funded. Although, compared to other French-speaking African countries, the share of the budget devoted to higher education remains too high in Burundi, as shown in the graph below, at the national level, the higher education is less funded.

\section{Graph 6: Evolution of the Higher Education Budget in Burundi}

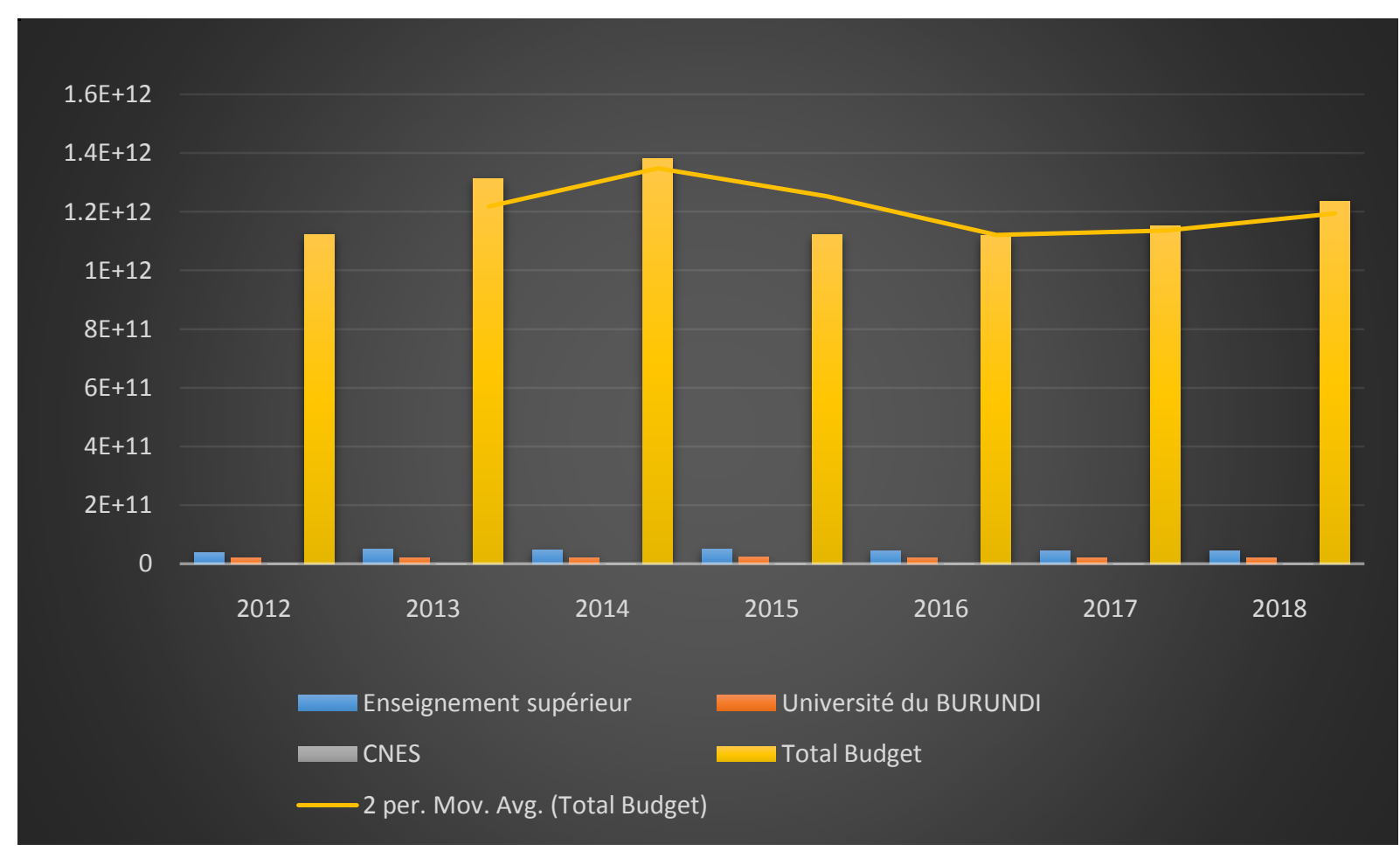

Source: Budget Act 2012-2018 
Comparison of the breakdown of public current expenditure by level of education in French-speaking subSaharan African countries, 2004 or close to 2004.

\begin{tabular}{|l|l|l|l|}
\hline Pays & \% Primary & \% Secondary & \% Higher Education \\
\hline Burundi & 44,4 & 28,0 & 27,3 \\
\hline Benin & 51 & 28 & 22 \\
Burkina Faso & 62 & 19 & 19 \\
Cameroun & 40 & 46 & 14 \\
Côte d'Ivoire & 47 & 37 & 16 \\
Guinée & 44 & 31 & 25 \\
Mauritanie & 44 & 39 & 17 \\
Niger & 60 & 27 & 13 \\
Sénégal & 54 & 19 & 28 \\
Tchad & 46 & 31 & 23 \\
Togo & 45 & 36 & 19 \\
\hline Moyenne des 10 pays & 49,3 & 31,3 & 19,6 \\
\hline Ratio Burundi / moyenne des 10 & 0,91 & 0,90 & 1,39 \\
pays & &
\end{tabular}

\section{Source: State Report on a National Educational System (RESEN), March 2017}

\section{Results Discussion}

We note that several factors characterized this pronounced and multifaceted crisis, but we develop here the main issues raised by stakeholders in our study and different documents.

\section{Teachers weakly qualified and unavailable}

The Burundi higher education in general has no sufficient qualified teachers, especially in private schools. The University of Burundi is the main public university of the country. "It has 9,300 students (in 2017), distributed across eight faculties and three institutes, with a number of $237 \mathrm{PhD}(46,2 \%)$ and 275 assistants $(53,7 \%)$ of all categories" (Masharabu, T. et al., 2017). Despite these numbers of qualified teachers, some difficulties are still raising the concern such as unavailability of the professors. Many of them are still doing studies in order to get $\mathrm{PhD}$ and masters: 107 out of $500(21,4 \%)$. Others are working while having already reached the limit age of retirement. They continue teaching due luck of succession. This issue appears to be addressed with the instauration of Doctoral School in the UB since 2017. The first doctoral students start to defend their thesis and will proceed with succession.

A lot of UB teachers give also courses at private universities as part time: the law prohibits teachers from being full-time in more than one higher institution, which can have a stabilizing effect and increase the quality of services. That situation has negative impact on student's supervision. Besides, young professors without enough qualification, say the doctorates providing a course at the University of Burundi are 181, or 36.2\%.

As shown in the graph above, of the 500 faculties at the University of Burundi, only 20 are ordinary professors, 70 associate professors, 159 lecturers, 12 lecturers, 183 master assistants and 56 assistants. In this situation, courses normally dispensed by a doctor can be taught by assistants.

As shown through the graph 4, this number is unequally distributed among faculties. Some faculties have enough teachers while others have few. Some areas such as law, Institute of Applied Statistics, the Institute of Physical Education and Sports, as well as the Institute of Commercial Sciences have few professors. The Faculty of Sciences, the Faculty of Arts and Humanities and the Institute of Applied Pedagogy register more professors.

In 2011, the University of Burundi had 162 thesis teachers, compared to 189 in 1985-86, (including cooperants). These professors were "split" between the UB, private universities and other universities in the sub-region. It is important to note that this movement of professors is almost one-way: all these universities draw from the University of Burundi.

This situation is not typical for Burundi. The existing literature shows that the same issues characterized others universities in Africa. Several African universities are facing a lack of qualified teachers. "The new private universities are obliged to recruit at mid-term teachers already working at the public universities. These moving professors do not really belong to none of the universities. They compromise universities competition. 
This means practically that in many countries, even if there are several universities, the expected effects of a real competition, namely a better quality of service with differentiated products, do not exist" (World Bank, 1997).Such situation is valid in French-speaking Africa (Loiret, 2008).

\section{Brain drain}

Burundi's repeated political crises have not spared the University of Burundi. The negative consequences have been felt on various aspects of this institution, including the brain drain. The low motivation of teachers, discouraged by their working conditions and remuneration, has led to a brain drain, particularly to Rwanda, and European countries in particular. Looking at the decade from the 1980s to the 1990s, for example, a large number of teachers had been trained. Between 1987 and 1993, 163 assistants from the University of Burundi were in training abroad, mainly in Canada, France and Belgium. Of these, only 80 returned; causing a loss of about 50\%.This has considerably reduced the number of permanent professors available while the number of students has increased steadily.

International scientific migration (brain drain in current terminology) is becoming less and less temporary, involving various actors (students, experts, scientists, technicians, etc.) and continues to generate a highly controversial debate about its configurations, dynamics and meanings. The issue of brain drain is one of the major challenges facing African countries in their fight for development (Ibrahima, 2005). The crisis in African education systems also rhymes with the political crises that have, in the course of the different years, shaken or even destabilized their universities (Feckoua, 2007).

The issue of brain drain is one of the major challenges facing African countries in their struggle for development. The brain drain is explained by various motivations: the search for more rewarding social and professional conditions, the need for human security, the ever-increasing international competition, the attractive policy of host countries, the impact of economic globalization, etc. The "nationalist" current considers the brain drain as "a scientific hemorrhage" for the benefit of the "basins for the reception of qualified African personnel" of the United States, Canada and Europe. These qualified professionals bring their skills to rich countries while their countries of origin need expertise to fertilize scientific and technological research and respond to concrete development concerns (Ibrahima, 2005).

\section{No research structure performant}

In Burundi, structured scientific research really started with the colonial era, and mainly targeted the agronomic field. These activities aimed to increase food crop production and promote export crops, including coffee and tea. The history of research in Burundi shows that this activity is currently rooting in the country via higher education institutions (public and private universities), and research centers.

Indeed, scientific and technological fields have been largely initiated and developed in specializations, including agronomy, engineering, mechanics, electro-mechanics, physics, chemistry, biology, etc. Despite these national scientific and technological efforts, the impact of the development of Science, Technology and Research (STR) in Burundi on the improvement of people's living conditions is not visible. This situation is linked, among other things, to the cyclical crises and wars that have seriously affected the country and have not spared research institutions. It is also the result of weak collaborative links between the STR sector (scientists and researchers) and productive sectors such as agriculture and industry. Since 2016, the UB endured a recognition process of its research structures to increase its scientific production and diversify the range of services provided to society (Masharabu et al 2018).

According to recent statistics from the United Nations Educational, Scientific and Cultural Organization (UNESCO) Institute of Statistics, followed by the World Bank (2017), Burundi spent only $0.14 \%$ and $0.12 \%$ of its GDP on Research and Development respectively in 2010 and $2011^{2}$.More than $90 \%$ of the budget depends on grants from the Government of Burundi, and only about $1 \%$ of the budget is allocated to research. The remainder is covered by bilateral and multilateral support, and to a lesser extent, by income generated through various services (RUFORUM, 2018).

According to the ranking process established by Journals Consortium (2015), which took into account 1447 African universities, the UB ranks 340th. For the other universities in the area, only three are on the list: Hope Africa University (615th), Light University of Bujumbura (979th) and University of NGOZI (1038th). The UB is gaining more and more points in the scientific world (RUFORUM, 2017). The results of "Ranking Web of Universities" by Webometrics for Africa for the years 2015 (294th / 563), 2016 (157th / 646) and 2017 (150th / 1522 universities targeted by the ranking), and considered by RUFORUM (2017), demonstrated the improvement in terms of performance of the UB.

\footnotetext{
${ }^{2}$ (https://donnees.banquemondiale.org/indicateur/GB.XPD. RSDV.GD.ZS? locations=BI).
} 120 
The Research Department of the UB was expanded to include innovation and became the Research and Innovation Department (RID). But this department had certain weaknesses, including: (i) the absence of a strategic plan, necessary to support the achievement of the expected results of the BMD reform in the field of research; (ii) the IRD services not having the human and financial resources required to carry out their respective missions; (iii) the University of Burundi review is not indexed in any regional or international database; and finally (iv) the number of laboratories is largely insufficient compared to student numbers. On the other hand, existing laboratories require extensive rehabilitation (SHABANI, 2017).

\section{Academic and Social Infrastructures not Adapted to Nowadays Conditions}

\section{State of the University of Burundi's Connection to Optical Fiber}

Today, 6 university of Burundi campuses located in Bujumbura (Mutanga, Rohero, Kamenge, Gihosha, Kiriri and CHUK) are interconnected within the university's computer network by high-speed radio link. The Internet bandwidth capacity is 38Mbps, $28 \mathrm{Mbps}$ provided by the Burundi Backbone System (BBS) company and $10 \mathrm{Mbps}$ provided by Lumitel Company. This Internet capacity is provided by optical fiber to the UNESCO Chair, which distributes it to the various campuses via radio links. More than $50 \%$ of University of Burundi computer scientists who participated in an online survey believe that this connection is good.

However, the $38 \mathrm{Mbps}$ bandwidth is far from being sufficient to use information and communication technologies as a teaching and research tool in a university with more than 13,000 students. As indicated in the Burundi University's strategic and operational computerization plan for the period 2015 to 2025, at least 250Mbps of symmetrical capacity is required (Shabani, 2018). However, it should be recalled that this plan was not approved by the UB, probably because it was very ambitious or unrealistic.

\section{Access to the Internet and the Use of ICT for Teaching and Learning}

ICT is not widely used in some Faculties/Institutes such as: FABI, Faculty of Law, IPA, IEPS, ISCO, FPSE, and FLSH. For FABI, this situation is mainly caused by the fact that the Zege Campus is not connected to the Internet. For other Faculties/Institutes, the reasons are multiple and include power outages, insufficient computers, and insufficient teacher capacity to use ICT in teaching and learning process (Rapport UB 2017). An online survey indicated that in general, at the Faculty of Science, teachers have their own laptops connected to the Internet while students have limited access to computers. At the level of this Faculty of Science, in addition to the Initiation to Computer Science courses, programming and modeling courses are given. Such courses cannot be given in theory. It is necessary to have a critical mass of computers and specific software.

At the Faculty of Medicine, the situation is different. Teachers who responded to a survey questionnaire on the evaluation of the BMD reform at UB indicated that they have satisfactory experience in the use of the Moodle platform, YouTube, E-learning and telemedicine. However, they pointed out the need to strengthening their capabilities in this area.

Only $4.2 \%$ of students who participated in an online survey indicated that they own a personal computer. This percentage is very low when you consider that the majority of African universities are in the process of setting up "one computer per student" programs. To ensure greater student access to the Internet, the University of Burundi has created 24 computer rooms containing a total of 462 computers connected to the UB local network by WIFI or cables. This situation means that the UB offers a ratio of more than 28 students per computer. Today, several African universities are implementing laptop computer programs per student.

More than $47 \%$ of the students who participated in the survey said that they have access to the computers available in the university's computer rooms. This percentage rises to $80 \%$ when it comes to computers available at the Central Library that are mainly reserved for students' research work. The digital campus, which contains the largest number of computers with 51 machines, is also partly used by students to do research. However, students cannot access it freely.

\section{Library}

The University of Burundi has a central library at the Mutanga campus with branches in the other campuses of the University. This Library also has digital documentary resources accessible to students. A Library Use Policy defines the conditions of use of the library as well as the lending conditions. In addition to the Central Library, other libraries are located on the various campuses according to the faculties and institutes. All these libraries are open during the day (including Saturday mornings) and in the evenings until $9 \mathrm{pm}$. These libraries are also accessible to students from other higher education institutions with respect to the request by the heads of the same institutions. 
Nevertheless, this library has a limited capacity given the high number of students from the UB and other private universities that request it. Not all private universities have libraries with sufficient books to facilitate research for students. To this end, they have signed agreements with the University of Burundi for their students to conduct research in the libraries of the University of Burundi. All students who want to do so make monthly subscriptions and acquire reader cards like their colleagues at the University of Burundi. But this is increasingly reducing the capacity reception of the UB libraries. Also, this library is not available online. It is not regularly populated, and when new books arrive, they take time to be encoded and actually effectively utilized. There is also no information system that can inform users of these new acquisitions (Library Responsible, 2018). And if new books arrive, posters are made and they often include bachelor's degree papers and internship reports.

\section{Limited Funding Capacity}

Like other African universities, the University of Burundi has experienced and continues to experience budget deficits. The budget allocated to this institution is used to finance most of the operating costs, leaving the investment aside. As shown in the graph above, the budget allocated to the University of Burundi cannot finance all the planned expenses. And if we look at the breakdown by need, we notice that most of the budget is for teachers and non-teaching staff salaries.

In recent years, the amount of the budget allocated to the University of Burundi has been approximately $50 \%$ of the requested budget. $100 \%$ financing is only provided for unavoidable recurring expenses (personnel costs, vehicle insurance, repayment of construction loans). As result, they represent a high percentage of the budget. Staff costs represent 75 to $80 \%$ of its amount. There are no funds for essential items as the acquisition of books, subscriptions and documentation, and contributions to international organizations.

The Burundian currency observed a slight devaluation in last years. The real exchange ratio is higher in Burundi than those of comparable countries. This situation leads to the rising prices on imported items in the country and lowering the purchasing power and, consequently the value of the funds provided to the university.

Since the 1980s, many governments and international donors, including the World Bank, have given relatively low priority to higher education. A narrow economic analysis - and in our view wrong - has contributed to the idea that public investment in universities and colleges is less profitable than that in primary and secondary schools, and that higher education increases income inequality. As result, higher education systems [...] suffer from a chronic lack of funds while facing increasing demand $[\ldots .$.

The method of financing higher education in French-speaking Africa is also an explanatory factor for the crisis that is undermining this sector. Scholarships and social assistance, formerly an expression of the welfare state in most African countries, are now only one memory in many countries and are often the subject of claims and therefore strikes (Makosso, 2006).

In Congo, the death of the welfare state and the socializing ideology prevailed in this country until the end of the 1980s had major implications for people's access to basic social services including education. Congo's Scholarship Reforms have substantially reduced the number of student's scholarship holders, thus substituting parents for the state in funding studies (Makosso, 2006)

Until 2002 the World Bank showed a new interest in higher education (Loiret, 2008). In a book entitled "Building Knowledge Societies", noting that "knowledge has become more than ever an essential factor of production in the global economy" (World Bank, 2002, P6), it acknowledges certain errors, revaluing the role of higher education and its social function while emphasizing ICTs and particularly distance education as a means of modernizing higher education. But this has not led governments to reconsider the key role played by universities in the economic development of nations.

\section{Problem to adapt to the $\mathrm{BMD}$ regime}

The BMD reform will transform several aspects and considerations of the system. Higher education is provided in universities and institutes. Since the academic year 2011-2012 two education systems coexist. An old system in which higher education is organized around short and long cycles and a new Baccalaureate - Master-Doctorate (BMD) pursuant to Act No. 1/22 of 30 December 2011. In the old system, training in the short cycles averaged 2 to 3 years, whereas it was generally 4 years in the long cycles, except in the faculties of agronomy and medicine where the training lasts 5 and 7 years respectively. As for the BMD system, it organizes higher education in the same way as the LMD reform

The act No. 1/22 of 30 December 2011 on the reorganization of higher education in Burundi redefined the act of 13 July 1989 on which, until 2011, the functioning of higher education was based. This law on the reform of higher education is undoubtedly the most important since the creation of the University of Burundi in 1964. 
Its objective is to improve student mobility not only within the national space, but also at the sub-regional, regional and international levels.

Indeed, to comply with the "Bologna Process", the country adopted at the beginning of the 2011-2012 school year, the LMD reform (Licence-Master-Doctorat) which applied to Burundians was named Baccalauréat-MasterDoctorat (BMD). Access to public higher education was until 2011, subject to the completion of the humanities graduation diploma (secondary school diploma), issued by the secondary school attended by the student. Students who enrolled in private higher education, on the other hand, could access it without obtaining this diploma. Since the law of December 2011, access to private higher education has been regulated in the same way as access to public higher education. Similarly, implementing the decree No.100/192 of 29 June 2012 specifies the procedures for obtaining a State diploma. It specifies that "the right to a state diploma is conditioned by obtaining a mark of at least 50\%". The latter is a synthesis of the grade obtained in school within the subjects covered by the State examination and the grade obtained on the examination itself. The school marks counts for $30 \%$ in the calculation of the final average while the state examination marks has a weight of $70 \%$.

Burundi, like several African countries, has moved towards the implementation of the BMD Reform within its higher education system. Considered as "a way of salvation" by some or as a "copy and paste «by others, this Reform challenges several aspects and considerations. At the same time, it attempts to propose a solution to a number of recurring problems while raising important issues (Goudiaby, 2009). The information system of the ministries in charge of education has not yet fully integrated these reforms into their data collection and presentation tools.

Consequently, administrative data on enrolment are sometimes collected according to the old system. The migration from the old university services database to the new one has been slow to materialize. This means that if data are requested from some universities, in this case the UB, sometimes data for some years of the new system, especially 2011-12, are not available.

Thus, we could deduce from this that the conditions for moving to such an important reform are not fully met, as Goudiaby points out in his analysis on Senegal's ownership of the LMD reform.

\section{Conclusion}

The crisis in educational systems is multifaceted, sometimes internal to states, sometimes external. But its impact is a source of immense difficulties that are difficult to control. The characteristics of the university crisis that have just been raised are due to a number of factors that determine them. The factors behind this crisis can be grouped into three categories: the population explosion, economic conditions, cyclical and structural factors, and structural adjustment policies.

The last one should be subject to rethink due to its importance in terms of present and future consequences. The Bologna Educational Process adoption in Burundi, with its components of Bachelor-Master-Doctorate is likely to generate multiple changes and would be implemented within a significant range of means that is not available now. Hence there is a real necessity to invest deeper in order to solve the crisis in the UB.

It is obvious that the crisis observed a dynamic move. At the beginning, it gave the appearance of economic crisis. Slowly, it came to be multifaceted and pronounced, and seems to be a structural and organizational crisis, as it touches on different issues such as Human Resources, infrastructures, financial aspects and demographic level in general beside the teaching system. Other studies would for example investigate on the Brain drain solutions and the alternative funding system at UB.

\section{Recommendations}

- Due to the university recurrent crisis, following recommendation can be formulated:

- In order to fill the existing knowledge gaps in sub-Saharan Africa, especially in Burundi and to create the critical mass of managers needed for economic take-off, universities would create the virtual university. This can resolve the recurrent crisis of African higher education. Nowadays, in most papers on education in Africa, distance learning is adorned with all the virtues and then, would be able to modernize the educational systems, opening the university to new public, reducing the costs of education, bringing up to standard the teachers, and increasing to the access to higher education.

- Related to the research, UB should make an effort to finance these activities at a higher level. However, steps must also be taken to encourage research initiatives whose publications not only serve to advance rank, but also to improve teaching and development in the country, visibility of his publications, and indexing their journals.

- In order to increase internet access, different faculties must multiply computers and give free access to students. The university can for example build some partnerships with telecommunication companies, 
- Regarding financial issues, university of Burundi should look for new partners, such as establishing SouthSouth cooperation and organize exchanges of experience and good practices with others universities or networks,

- The University of Burundi should also be encouraged to be self-financing, in particular through participation in consultancy work and the establishment of contract research funds.

\section{References}

Diaz, s. g. (2019). Sat0726-hpr eHealth consultations in rheumatology managed by nursing. Spanish national descriptive study.

DRISSA DIAKATE, (2000). La crise scolaire au Mali, Nordic Journal of African Studies 9(3):6-28(2000)

Feckoua, L. L. (2007). L'évolution des systèmes éducatifs en Afrique subsaharienne depuis le 1er Congrès des écrivains et artistes noirs (1956). Présence Africaine, 175-176-17(1), 163. https://doi.org/10.3917/presa.175.0163

Goudiaby, J. (2009). Le Sénégal dans son appropriation de la Réforme LMD : déclinaison locale d'une Réforme " globale ». 7, 79-93.

Gaillard, 1998, Population dynamics of large herbivores: variable recruitment with constant adult survival,

Ibrahim Amadou Dia, (2005). Déterminants, enjeux et perceptions des migrations scientifiques internationnales africaines:le cas du Sénégal,Stichproben.Wiener Zeitschrift für kritische Afrikastudien Nr 8/2005,5.Jg.

Loiret, P.-J. (2008). L'université virtuelle africaine, l'enseignement à distance en trompe-l'oeil ? Distances et Savoirs, 6(2), 187-209. https://doi.org/10.3166/ds.6.187-209

Makosso, B. (2006). La crise de l'enseignement supérieur en Afrique francophone: une analyse pour les cas du Burkina Faso, du Cameroun, du Congo, et de la Côte d' Ivoire (Vol. 4).

Masharabu et al. (2017) . La Recherche-Développement à l'Université du Burundi : bilan, défis et perspectives, RUFORUM Working Document Series (ISSN 1607-9345) No. 15 : 121- 130.

Available from http://repository.ruforum.org

Midende, 2011, Analyse du fonctionnement et du financement de l'enseignement supérieur public, Bujumbura

Ministère de l'Education Nationale, Rapport d'Etat sur le Système Educatif National (RESEN 2012\&2017),

Odebero,S.O.(2010,Avril).Crisis in Financing and Management of Kenya Higher Education: Implications for planning reform agenda. Paper presented at Educationnal Management Society of Kenya Conference held at Migori Teachers College, April 12-14, 2010

Pierre-Jean Loiret, (2008), L'Université Virtuelle Africaine, L'enseignement à Distance en trompe-l'œil?, Cairn.info/revue-distance-et-savoirs-2008-2-page-187.htm

Ministère de l'enseignement supérieur et de la Recherche Scientifique, Rapport des statistiques de l'Enseignement Supérieur, novembre 2019

République du Burundi, Ministère de l'enseignement supérieur et de la Recherche Scientifique. Plan d'actions de mise en cuvre de la politique nationale de recherche et de l'innovation technologique, Bujumbura,mai 2014

RUFORUM Working Document Series (ISSN 1607-9345)N015:93-106. Available from https//repository.ruforum.org,Contribution de l'Université du Burundi à la réalisation des Objectids de Développement Durable, Banyankimbona,G 2018

Nahas,A.Angula.(2003). Les défis internes et externes de l'enseignement supérieur en Afrique subsaharienne, Cahiers édités par le Centre Tricontinental, Louvain-la-Neuve. Alternatives Sud,vol.X(2003) 3

Université du Burundi, Cabinet du Recteur, novembre (2017), Rapport d'autoévaluation institutionnelle de l'Université du Burundi

Université du Burundi, Cabinet du Vice Recteur, août 2018, Annuaire Statistique des Enseignants et Etudiants de l'UB, Année Académique 2017-2018

Shabani, JUMA. (2018), Rapport d'évaluation définitif de la réforme BMB à l'Université du Burundi, P44,

Zejnullahi, E. D., Zogaj, J., Halko-Shatri, S., Duraku, B., Thaqi, A., Sopaj, B., ... \& Hoxha, V. (2018). Assessment of enterprise level management in construction sector in Kosovo

Site

(Https://donnees.banquemondiale.org/indicateur/gb.xpd. RSDV.GD.ZS? locations=BI). 